\title{
Commentary: Scratching the surface of sustainable cardiac surgery in sub-Saharan Africa: A voice that needs to be heard
}

\author{
Victor A. Ferraris, MD, PhD, ${ }^{a}$ and A. Thomas Pezzella, $\mathrm{MD}^{\mathrm{b}}$ \\ From the ${ }^{\mathrm{a}}$ University of Kentucky, Lexington, Ky; and ${ }^{\mathrm{b}}$ International Children's Heart Fund, Boca Raton, Fla. \\ Disclosures: Authors have nothing to disclose with regard to commercial support. \\ Received for publication Jan 16, 2019; accepted for publication Jan 17, 2019; available ahead of print March 9, \\ 2018. \\ Address for reprints: Victor A. Ferraris, MD, PhD, University of Kentucky, A301 Kentucky Clinic, 740 South \\ Limestone, Lexington, KY 40536-0284 (E-mail: ferraris@uky.edu). \\ J Thorac Cardiovasc Surg 2019;158:1394-6 \\ $0022-5223 / \$ 36.00$ \\ Copyright $\Subset 2019$ by The American Association for Thoracic Surgery \\ https://doi.org/10.1016/j.jtcvs.2019.01.056
}

In this issue of the Journal, Forcillo and co-authors ${ }^{1}$ developed a comprehensive and exhaustive report on a structured approach to developing and sustaining cardiac surgery in a subset of African countries. Their article describes assessments of the needs of African countries that would allow development and modernization of cardiac surgery in a population with traditional shortfalls in this area. They sampled 3 countries (Namibia, Zambia, and Uganda) to describe challenges and opportunities, as well as past efforts and current initiatives in these countries. They surveyed surgical facilities, interviewed stakeholders, and developed an assessment questionnaire that could be used in a typical resource-constrained environment. Theses authors recognized that training infrastructure is being built, but comprehensive multidisciplinary care systems are lacking. There are major resource bottlenecks that likely block improvements in surgical programs. The authors suggest that the questionnaire used for their assessments might assist health ministries to build cardiac surgical programs in other resource-constrained African countries that include upgrading existing programs, reinstating failed programs, and developing in situ new programs. There remains some questions, concerns, and comments regarding this article.

Readers of the Journal realize that this article is atypical in many ways compared with the usual journal articles. It does not contain a randomized controlled trial or even an observational study of surgical patients. Yet it is uniquely worth reading. It represents perhaps the first overall evaluation of cardiac surgery programs in 3 African countries. The article by Forcillo and colleagues ${ }^{1}$ begins the process of identifying problems and outlining solutions to the development of sustainable cardiac surgical care in sub-Saharan Africa. The impact of this article has the potential to affect many thousands of patients in need of cardiac surgical care in an environment that mostly lacks any semblance of this

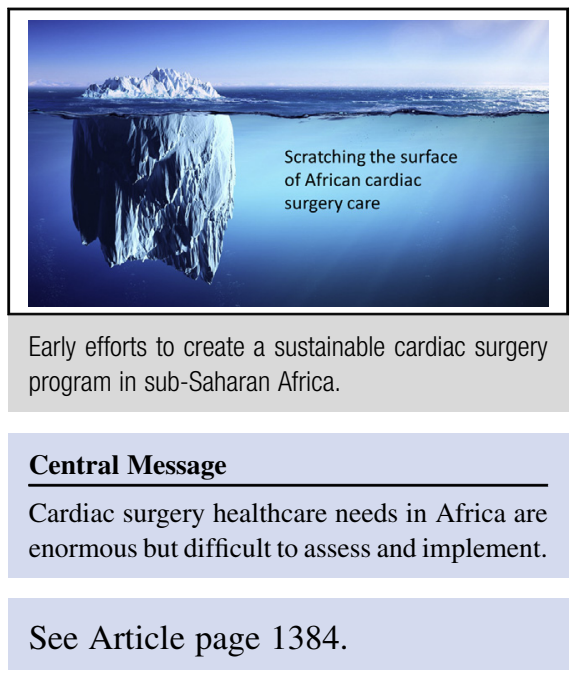

type of care at present. It is entirely conceivable that the implications of this article can alter patient outcomes favorably to a greater extent than most articles that appear in the Journal. There is no doubt that the authors' prescription for assessment and implementation of cardiac surgical care has both enormous potentials to save lives and improve patient care while at the same time facing almost insurmountable hurdles toward this goal in many parts of the African continent (Table 1).

There are enormous gaps in healthcare in the African continent, and Forcillo and colleagues ${ }^{1}$ developed their assessments in 3 relatively stable countries in sub-Saharan Africa. Most African countries are confronted with the burden of diseases that include communicable and noncommunicable noncardiac diseases. The threat of recurrence of Ebola virus and the devastating effects of 2 generations of human immunodeficiency virus still remain in the background of many African countries. There are substantial questions about the generalizability of the authors' assessments and recommendations. For example, according to Google, there are currently 15 African countries involved in war or experiencing postwar conflict and tension. In West Africa, these countries include Cote d'Ivoire, Guinea, Liberia, Nigeria, Sierra Leone, and Togo. In East Africa, the countries include Eritrea, Ethiopia, Somalia, Sudan, and Uganda. Armed conflict has changed so that governments are confronted with many different armed groups. There is a question whether violent political extremism will move from the 
TABLE 1. Problems with initiation and sustainability of cardiac surgery in sub-Saharan Africa

\begin{tabular}{|c|c|c|}
\hline Problems & Hurdles & Possible solutions \\
\hline $\begin{array}{l}\text { Maldistribution of } \\
\text { health care }\end{array}$ & $\begin{array}{l}\text { - Government instability with frequent changes, } \\
\text { corruption, incompetence, and disconnect from the } \\
\text { population needs and wants }\end{array}$ & $\begin{array}{l}\text { - Neutral cardiac care available to all sides in conflict in } \\
\text { a conflict-free zone. Needs include transport and } \\
\text { funding among others. Explore public/private } \\
\text { insurance initiatives. }\end{array}$ \\
\hline Cost issues & $\begin{array}{l}\text { - Sustainability and upkeep after initial purchases are } \\
\text { the issues. Logistics and biomedical support are major } \\
\text { challenges. } \\
\text { For most programs in Africa, the patient must pay for } \\
\text { the drugs, devices (valves, H/L device), disposables, } \\
\text { and specialty-specific needs (cardiac, anesthesia), } \\
\text { total } ~ \$ 500, \$ 1000 \text { out of pocket, virtually } \\
\text { unaffordable for most. }\end{array}$ & $\begin{array}{l}\text { Bricks/mortar, infrastructure, equipment/supplies/ } \\
\text { devices/disposables/drugs are the easy issue because } \\
\text { they can be done with money from government, } \\
\text { foreign donations, corporate discounts, and so forth. }\end{array}$ \\
\hline $\begin{array}{l}\text { Priorities in health care } \\
\text { do not always include } \\
\text { cardiac surgery }\end{array}$ & - Local hospital conflicts and competition for resources & $\begin{array}{l}\text { - Training of primary care in cardiac needs and } \\
\text { assessments } \\
\text { - Need ready referral outlet } \\
\text { - Cooperation between public health (cohorts) and } \\
\text { medical (curative) }\end{array}$ \\
\hline $\begin{array}{l}\text { Big picture for cardiac } \\
\text { care - regional care } \\
\text { programs }\end{array}$ & $\begin{array}{l}\text { - In situ basic programs have failed or not even gotten } \\
\text { off the ground. }\end{array}$ & $\begin{array}{l}\text { Strategy for other African programs - regional hub } \\
\text { program may be better alternative. Countries can } \\
\text { choose which regional hub to align with. Some } \\
\text { countries may never be able to establish a program and } \\
\text { may require an alliance with a regional hub. }\end{array}$ \\
\hline Training & $\begin{array}{l}\text { Team training (CT surgery, anesthesia, perfusion, } \\
\text { nursing, OR, ICU, ward, clinic) is lacking. HR is a big } \\
\text { challenge. Getting hands on training in or out of } \\
\text { country is crucial. Biomedical support lacking. }\end{array}$ & $\begin{array}{l}\text { Out-of-country leadership host programs - access, } \\
\text { awareness, affordability, accountability, sustainability, } \\
\text { transparency, exit strategy }\end{array}$ \\
\hline NGOs & $\begin{array}{l}\text { NGOs need to be involved. They represent the boots } \\
\text { on the grand. Yet the NGOs do not cooperate their } \\
\text { efforts with other NGOs working in the same center. } \\
\text { Bambini is one exception. }\end{array}$ & $\begin{array}{l}\text { The majority of NGOs are pediatric cardiac. The ideal } \\
\text { NGO presence should start with the traditional } \\
\text { progression of general surgery to thoracic, adult } \\
\text { cardiac, and then pediatric surgery. }\end{array}$ \\
\hline
\end{tabular}

$\overline{H / L}$, Heart/lung device; $C T$, cardiothoracic; $O R$, operating room; $I C U$, intensive care unit; $H R$, human resources; $N G O$, non-governmental organization.

Middle East to Africa, and it is possible that Al Qaeda and the Islamic State will find solid footing in Africa as they are displaced from the Middle East. So, although the potential for improvement is enormous, the prospect that any significant improvement will occur rapidly, or even soon, is far from certain. Accounting for the uncertainty of these destabilizing factors is not an exact science. It is difficult, and even dangerous in some African countries, to perform a "needs assessment" in a destabilized war environment, but to ignore these cardiac surgical needs seems plain wrong, both for humanitarian reasons and for providing basic health needs. ${ }^{2}$ To their credit, the authors embarked on a journey of cardiac surgical needs assessment with a full understanding of these hurdles.

It is easy to minimize the impact of cardiac surgical care in an environment that is unstable, resource constrained, and lacking important infrastructure. There are plenty of other needs in this environment, including the following:

- enhanced plans of improved trauma care widely disseminated, especially in conflict zones;
- need for increased emergency department and trauma centers, as well as basic advanced trauma life support training;

- improved simple public health measures disseminated widely in the regions surrounding referral centers;

- development of transport systems to facilitate access of patients to advanced care centers; and

- protected hospital/treatment areas free from war-related conflict zones readily available to all sides in the conflict.

There are questions about the advisability of developing advanced care treatment systems like cardiac surgical care, when there are so many other areas lacking complete medical systems of care. Making the case for cardiac surgery must stress the sociopolitical and financial impacts of the increase in coronary artery disease, the lingering burden of rheumatic heart disease, and the increase in congenital heart disease, be it neonatal or the backlog of patients with chronic congenital heart disease. Is it reasonable to develop advanced care treatment systems such as cardiac surgery without some consideration of global health care needs 
and interventions in sub-Saharan Africa? This question gets at the issue of health care priorities. In rationing scarce healthcare funds, is it reasonable to spend money on advanced cardiac surgical care at the expense of other more common and perhaps more lethal disease (eg, human immunodeficiency virus, tuberculosis, diarrheal diseases, malaria)? How are healthcare dollars apportioned in African countries? How should they be apportioned? How should the recommendations of Forcillo and colleagues ${ }^{1}$ be factored into the total healthcare cost structure of African countries? The cost for this advanced care will always surface and may force governments and payors to make difficult decisions that ultimately result in healthcare rationing with exclusion of some patients who are unable or unwilling to pay for care. Suggestions about care improvements must always involve discussions about how to pay for services. Things like capitation and government-funded insurance plans do not have much meaning in the context of financially struggling African countries. The roles of the private sector and the local/international corporate sectors need to be defined. Some discussions of the ability of countries to pay for advanced care delivery must be an important part of any plan to improve cardiac surgical care in this region.

A review of medical services in Africa cannot be complete without considering non-governmental organizations (NGOs) that provide health care to many parts of Africa. We wonder if authors think that NGOs are part of the solution to some of these problems? There is some doubt that NGOs can provide meaningful help or change in Africa. ${ }^{3,4}$ Are NGOs capable of serving a "primary care" function and screening for patients who need more advanced care? It is a little simplistic to describe elaborate advanced surgical care plans without having some means of screening and triage of patients who need advanced facilities or advanced care procedures. Working with existing medical resources like NGOs will provide some needed help in the big picture of delivering cardiac surgical care in the region.

Having raised these seemingly insurmountable issues that may limit advanced cardiac surgical care, it is simply wrong to abandon any efforts at this advanced care delivery. It is wrong for moral, ethical, and too numerous to count other reasons, not the least of which is a cohort of adult African patients with cardiac surgical needs. Just because it looks like an unsolvable problem does not mean it should be ignored or abandoned. To their credit, Forcillo and co-authors ${ }^{1}$ are shining a light on advanced surgical care in sub-Saharan Africa, even though they may be only scratching the surface of a sustainable cardiac surgical care plan. By publishing this article in the Jour$n a l$, there is a real hope that exposing the needs and gaps in cardiac surgical care in sub-Saharan Africa will provide some support and encouragement to efforts like those described by Forcillo and colleagues. ${ }^{1}$ The future must ultimately provide cardiac surgical care to a population who needs it more than most. The article by Forcillo and colleagues ${ }^{1}$ provides a way forward with small steps at first, but ultimately with more.

\section{References}

1. Forcillo J, Watkins DA, Brooks A, Hugo-Hamman C, Chikoya L, Oketcho M et al. Making cardiac surgery feasible in African countries: experience from Namibia, Uganda, and Zambia. J Thorac Cardiovasc Surg. 2019;158:1384-93.

2. Cox JL. Presidential address: changing boundaries. J Thorac Cardiovasc Surg. 2001;122:413-8.

3. Dicklitch S. The Elusive Promise of NGOs in Africa: Lessons From Uganda. New York: St. Martin's Press; 1998.

4. Brass JN. Allies or Adversaries: NGOs and the State in Africa. New York, NY: Cambridge University Press; 2016. 